\title{
PENGARUH STRUKTUR MODAL DAN WORKING CAPITAL TURNOVER TERHADAP PROFITABILITAS (Studi Empiris pada Pembayar Pajak Perusahaan yang di Periksa oleh Kantor Pelayanan Pajak Madya Jakarta Pusat)
}

\author{
Amdani Dan Desnerita \\ Fakultas Ekonomi Universitas Persada Indonesia (YAI) \\ Email:amdani58@gmail.com dan Email: desnerita@gmail.com
}

\begin{abstract}
This research aims to obtain information on how the influence of the Capital Structure and Working Capital Turnover either individually or jointly (simultaneously) on the profitability of the company Taxpayers inspected by the Tax Office Madya Jakarta Pusat. The population in this study are companies Taxpayers are inspected by the tax office Madya Jakarta Pusat period 2008-2012, the sampling method with purposive sampling technique, with a total sample of 15 companies. The data used is secondary data, motode analysis is the analysis of panel data with Common Effect Model (pooled least squares), Fixed Effect Model (FEM), and Random Effect Model (REM) to determine the accuracy of the model used the model needs to be tested between another test Model Estimation Methods, classical assumption underlying the regression model. The results of processing and analysis of data obtained from the result is the effect of the Capital Structure and Working Capital Turnover On Profitability significantly, either partially or simultaneously.
\end{abstract}

Keywords: return on assets, capital structure (Debt Equity) and Capital Turnover

Abstrak: Penelitian ini bertujuan untuk mendapatkan informasi tentang bagaimana pengaruh Struktur Modal dan Perputaran Modal Kerja baik secara individu atau bersamasama (simultan) terhadap profitabilitas Wajib Pajak perusahaan diperiksa oleh Kantor Pajak Madya Jakarta Pusat. Populasi dalam penelitian ini adalah perusahaan Wajib Pajak yang diperiksa oleh kantor pajak Madya Jakarta Pusat periode 2008-2012, metode sampling dengan teknik purposive sampling, dengan jumlah sampel 15 perusahaan. Data yang digunakan adalah data sekunder, analisis motode adalah analisis data panel dengan Umum Efek Model (pooled kuadrat terkecil), Fixed Effect Model (FEM), dan Random Effect Model (REM) untuk menentukan akurasi dari model yang digunakan kebutuhan Model untuk diuji antara Model tes lain Estimasi Metode, asumsi klasik yang mendasari model regresi. Hasil pengolahan dan analisis data yang diperoleh dari hasilnya adalah efek dari Struktur Modal dan Perputaran Modal Kerja Terhadap Profitabilitas secara signifikan, baik secara parsial maupun secara simultan.

Kata kunci: return on assets, capital structure (Debt Equity) and Capital Turnover

\section{PENDAHULUAN}

Dewasa ini perusahaan dituntut untuk memiliki manajemen yang baik agar dapat tetap menjalankan kegiatan operasinya, hal ini dikarenakan perkembangan dunia usaha yang semakin meningkat dengan persaingan yang tinggi. Perkembangan suatu perusahaan dititikberatkan pada bagaimana cara perusahaan tersebut mencapai tujuan utamanya, yaitu tercapainya laba yang telah ditetapkan. Besar kecilnya laba yang diperoleh perusahaan 
merupakan ukuran keberhasilan perusahaan dalam mengelola usahanya. Perusahaan selalu melaporkan laporan keuangannya pada instansi pajak cenderung melaporkan hutang yang cukup besar dan tingkat laba yang kecil dan akhirnya penetapan beban pajaknya rendah dari semestinya, oleh sebab itu instansi pajak selalu melakukan pemeriksaan laporan keuangan perusahaan yang teridentifikasi melakukan pelanggaran tersebut.

Kebijakan hutang perlu di kelola dengan baik dengan demikian akan terbentuk struktur modal perusahaan yang terdiri dari, modal sendiri (equity), hutang jangka panjang (long term debt). Hutang jangka panjang menurut Soemarso (2005:70), hutang jangka panjang (long term debt) adalah hutang dengan jangka waktunya panjang, umumnya lebih dari 10 tahun. Menurut Sawir (2005:129) Modal kerja adalah keseluruhan aktiva lancar yang dimiliki perusahaan, atau dapat pula dimaksudkan sebagai dana yang harus tersedia untuk membiayai kegiatan operasi perusahaan sehari-hari. Modal kerja merupakan masalah pokok perusahaan. Kesalahan dalam modal kerja merupakan sebab utama kegagalan suatu perusahaan. Oleh sebab itu, perputaran modal kerja (net working capital turn over) haruslah cepat.

Tingkat efektivitas penggunaan modal kerja menjadi sangat penting untuk pertumbuhan dan kelangsungan perusahaan dalam jangka panjang. Apabila perusahaan kekurangan modal kerja untuk memperluas penjualan dan meningkatkan produksinya, maka besar kemungkinan akan kehilangan pendapatan dan keuntungan. Profitabilitas menurut Riyanto (2008) adalah menggambarkan kemampuan perusahaan mendapatkan laba melalui semua kemampuan dan sumber yang ada seperti penjualan, kas, modal, jumlah karyawan, jumlah cabang dan sebagainya. Brigham dan Daves (2010) menyatakan bahwa profitabilitas adalah hasil akhir dari sejumlah kebijakan dan keputusan yang dilakukan oleh perusahaan. Husnan dan Pudjiastuti (2012) menyatakan bahwa keberhasilan perusahaan salah satunya dapat diukur dari profitabilitasnya sehingga dalam penelitian ini digunakan profitabilitas yang merupakan ukuran kemampuan perusahaan untuk menghasilkan laba dari modal sendiri yang dimiliki perusahaan.

Penelitian yang dilakukan oleh Abdul Raheman dan Mohamed Nasr (2007) pada tahun 1999-2004 pada Karachi Stock Exchange di Pakistan menunjukkan bahwa secara simultan modal kerja berpengaruh positif signifikan terhadap profitabilitas.Sundjaja \& Barlian (2009:114) mengemukakan bahwa rasio hutang jangka panjang terhadap total aktiva dapat menunjukkan persentase total aktiva yang dibiayai oleh ekuitas perusahaan. Jika rasio hutang jangka panjang terhadap total aktiva meningkat, laba meningkat karena perusahaan menggunakan banyak pembiayaan jangka panjang yang berdampak pada naiknya resiko perusahaan atas pembayaran hutang, hal ini akan mempengaruhi rentabilitas perusahaan tersebut.

Penelitian Marc Deloof (2003) melakukan penelitian terhadap 109 perusahaan non finansial di Belgia mengemukakan manajemen modal kerja berpengaruh terhadap profitabilitas perusahaan, hal ini terlihat jika jumlah hutang meningkat berarti akan meningkatkan resiko keuangan dan apabila perusahaan tidak dapat mengelola dana dari hutang dengan baik akan berdampak negatif dan menurunkan profitabilitas

Penelitian yang dilakukan oleh Danuletio (2010) dan Mathuva (2009) menemukan bahwa struktur hutang berpengaruh negatif signifikan terhadap profitabilitas. Didukung oleh penelitian Nugraha (2009) menyatakan bahwa variabel pendanaan modal yang diperoleh dari hutang jangka panjang berkolerasi negatif signifikan terhadap profitabilitas dan penelitian Hanum (2008) menyatakan bahwa pendanaan modal Kerja berpengaruh 
tidak signifikan terhadap profitabilitas. Berbeda dengan Utwal (2011) bahwa pendanaan modal kerja berpengaruh secara negatif signifikan terhadap profitabilitas perusahaan.

Berdasarkan latar belakang masalah yang telah dipaparkan di atas, maka penulis mengidentifikasikan masalah-masalah Kebijakan hutang perlu di kelola secara baik karena kalau terlampau tinggi dapat menurunkan nilai perusahaan diduga akan dapat mempengaruhi profitabilitas dalam kegiatan perusahaan terutama untuk melakukan pembelanjaan perluasan perusahaan (ekspansi) atau modernisasi dari perusahaan. Likuiditas perusahaan akan terganggu disebabkan peningkatan hutang jangka panjang untuk melakukan pembelanjaan perluasan perusahaan (ekspansi) atau modernisasi dari perusahaan akan menyebabkan banyak dana/modal pinjaman yang tertanam (dinvestasikan) dalam bentuk aktiva tetap, seperti tanah dan mesin-mesin serta peralatan dan pada akhirnya akan mempengaruhi profitabilitas perusahaan. Jumlah hutang meningkat berarti dengan meningkatnya rasio hutang jangka panjang terhadap total aktiva akan meningkatkan resiko keuangan dan apabila perusahaan tidak dapat mengelola dana dari hutang dengan baik akan berdampak negatif dan menurunkan profitabilita diduga akan dapat mempengaruhi profitabilita perusahaan dimasa akan datang. Modal kerja yang dipergunakan membiayai kegiatan operasi perusahaan sehari-hari yang tidak efisien, seperti periode pengumpula piutang (debt collection) yang terlalu lama dan persedian yang lama tersimpan diduga akan dapat mempengaruh profitabilita perusahaan. Modal kerja tidak efisien terlihat dari perputaran modal kerja (net working capital turn over) yang lambat, hal ini dapat diduga akan mempengaruhi profitabilitas perusahaan.

Masalah yang akan diteliti selanjutnya dapat dirumuskan dalam bentuk pertanyaan sebagai berikut: (1) Apakah ada pengaruh struktur modal terhadap profitabilitas pada perusahaan wajib pajak yang diperiksa oleh Kantor Pelayanan Pajak Madya Jakarta Pusat; (2) Apakah ada pengaruh perputaran modal kerja terhadap profitabilitas pada perusahaan wajib pajak yang diperiksa oleh Kantor Pelayanan Pajak Madya Jakarta Pusat; (3) Apakah ada pengaruh struktur modal dan perputaran modal kerja secara bersama-sama (simultan) terhadap profitabilitas pada perusahaan wajib pajak yang diperiksa oleh Kantor Pelayanan Pajak Madya Jakarta Pusat.

Tujuan dalam penelitian ini adalah: (1) Untuk mengetahui pengaruh struktur modal terhadap profitabilitas pada perusahaan wajib pajak yang diperiksa oleh Kantor Pelayanan Pajak Madya Jakarta Pusat; (2) Untuk mengetahui pengaruh perputaran modal kerja (net working capital turn over) terhadap profitabilitas pada perusahaan wajib pajak yang diperiksa oleh Kantor Pelayanan Pajak Madya Jakarta Pusat; (3) Untuk mengetahui pengaruh struktur modal dan modal kerja (net working capital turn over) secara bersamasama (simultan) terhadap profitabilitas pada perusahaan wajib pajak yang diperiksa oleh Kantor Pelayanan Pajak Madya Jakarta Pusat.

\section{LANDASAN TEORI}

Profitabilitas. Setiap perusahaan selalu berusaha untuk meningkatkan profitabilitasnya. Jika perusahaan berhasil meningkatkan profitabilitasnya, dapat dikatakan bahwa perusahaan tersebut mampu mengelola sumber daya yang dimilikinya secara efektif dan efisien sehingga mampu menghasilkan laba yang tinggi. Sebaliknya, sebuah perusahaan memiliki profitabilitas rendah menunjukkan bahwa perusahaan tersebut tidak mampu mengelola sumber daya yang dimilikinya dengan baik, sehingga tidak mampu menghasilkan laba tinggi. 
Menurut Munawir (2007:33), yang dimaksud profitabilitas adalah: "menunjukkan kemampuan perusahaan untuk menghasilkan laba selama periode tertentu”. Menurut Sartono (2002:120), profitabilitas adalah kemampuan perusahaan memperoleh laba dalam hubungannya dengan penjualan, total aktiva, maupun modal sendiri. Jumlah laba bersih kerap dibandingkan dengan ukuran kegiatan atau kondisi keuangan lainnya seperti penjualan, aset, ekuitas pemegang saham untuk menilai kinerja sebagai suatu persentase dari beberapa tingkat aktivitas atau investasi. Profitabilitas adalah rasio yang menunjukkan keberhasilan perusahaan di dalam menghasilkan keuntungan (Ang, 2007:18). Selain itu, profitabilitas adalah rasio yang mengukur efektifitas manajemen yang ditunjukkan oleh laba yang dihasilkan dari penjualan investasi perusahaan (Weston \& Copeland, 2010:23). Sedangkan Brigham dan Houston (2009:89) mengatakan bahwa profitabilitas adalah hasil bersih dari serangkaian kebijakan dan keputusan”.

Berdasarkan pendapat di atas, maka dapat disimpulkan bahwa profitabilitas atau rentabilitas adalah usaha untuk menghasilkan keuntungan atau laba.Profitabilitas yang digunakan sebagai kriteria penilaian hasil operasi perusahaan mempunyai tujuan pokok dan dapat dipakai sebagai berikut: (a) Profitabilitas dapat dimanfaatkan untuk menggambarkan kriteria yang sangat diperlukan dalam menilai sukses suatu perusahaan dalam hal kapabilitas dan motivasi dari manajemen; (b) Suatu alat untuk membuat proyeksi laba perusahaan karena menggambarkan korelasi antar laba dan jumlah modal yang ditanamkan; (c) Suatu alat pengendalian bagi manajemen. Profitabilitas dapat dimanfaatkan oleh pihak internal untuk menyusun target, budget, koordinasi, evaluasi hasil pelaksanaan operasi perusahaan dan dasar pengambilan keputusan penanaman modal.

Rasio profitabilitas atau rasio rentabilitas merupakan analisis terhadap laba dan berbagai unsur yang membentuk laba merupakan aspek penting, karena kelangsungan hidup dan sukses tidaknya suatu perusahaan sangat tergantung pada kemampuannya dalam menghasilkan laba. Analisis profitabilitas perusahaan merupakan bagian utama analisis laporan keuangan. Seluruh laporan keuangan dapat digunakan untuk analisis profitabilitas, namun yang paling penting adalah laporan laba rugi.

Menurut Brigham (2006:89) mengenai rasio profitabilitas: "Rasio profitabilitas mengukur efektifitas manajemen secara keseluruhan seperti terlihat dari pengembalian yang dihasilkan oleh penjualan dan investasi”.

Harahap, Sofyan Safri (2001: 304) menjelaskan bahwa: "Rasio rentabilitas atau disebut juga profitabilitas menggambarkan kemampuan perusahaan mendapatkan laba melalui semua kemampuan dan sumber yang ada seperti kegiatan penjualan, kas, modal, jumlah karyawan, jumlah cabang dan sebagainya”. Sedangkan menurut Husnan dan Pudjiastuti (2002:73) yaitu:"Rasio profitabilitas dimaksudkan untuk mengukur efisiensi penggunaan aktiva perusahaan”. Sartono (2011: 119) berpendapat bahwa profitabilitas adalah kemampuan perusahaan memperoleh laba dalam hubungannya dengan penjualan, total aktiva maupun modal sendiri, sedangkan menurut Riyanto (2011:112) adalah kemampuan perusahaan untuk menghasilkan laba selama periode tertentu. Lebih lanjut Darsono (2006:55), mengatakan bahwa profitabilitas adalah kemampuan untuk memperoleh laba, yang terdiri dari: laba kotor, laba operasi dan laba bersih.

Maka berdasarkan ketiga pengertian di atas, dapat disimpulkan bahwa rasio yang dapat digunakan untuk mengukur kemampuan perusahaan dalam menghasilkan laba disebut rasio profitabilitas. 
Struktur Modal. Ada beberapa pengertian atau definisi dari struktur modal oleh beberapa ahli yang menuangkannya dalam buku mereka, diantaranya adalah: Menurut Weston dan Copeland (2010:245) memberikan definisi struktur modal sebagai pembiayaan permanen yang terdiri dari utang jangka panjang, saham preferen, dan modal pemegang saham. Nilai buku dari modal pemegang saham terdiri dari saham biasa, modal disetor atau surplus modal dan akumulasi laba ditahan. Bila perusahaan memiliki saham preferen, maka saham tersebut akan ditambahkan pada modal pemegang saham. Sedangkan menurut Dermawan Sjahrial (2013:179), "Struktur modal merupakan perimbangan antara penggunaan modal pinjaman yang terdiri dari utang jangka pendek yang bersifat permanen”. Menurut Gitman (2009:488), definisi struktur modal adalah sebagai berikut: "Capital Structure is the mix of long term debt and equity maintained by the firm". Struktur modal perusahaan menggambar-kan perbandingan antara utang jangka panjang dan modal sendiri yang digunakan oleh perusahaan. Ada dua macam tipe modal menurut Gitman (2009:493) yaitu modal utang (debt capital) dan modal sendiri (equity capital). Tetapi dalam kaitannya dengan struktur modal, jenis modal utang yang diperhitungkan hanya utang jangka panjang.

Teori Struktur Modal. Menurut Sjahrial (2013:180), teori struktur modal di bagi dua bagian: Pertama. Teori struktur modal tradisional yang terdiri dari:

1. Pendekatan laba bersih (net income approach). Pendekatan laba bersih mangasumsikan bahwa investor mengkapitalisasi atau menilai laba perusahaan dengan tingkat kapitalisasi yang konstan dan perusahaan dapat meningkatkan jumlah hutangnya dengan tingkat biaya hutang yang konstan pula. Karena tingkat kapitalisasi dan tingkat biaya hutang konstan maka semakin besar jumlah hutang yang digunakan perusahaan, biaya modal rata-rata tertimbang semakin kecil sebagai akibat penggunaan hutang yang semakin besar, nilai perusahaan akan meningkat.

2. Pendekatan laba operasi (net operating income approach). Pendekatan ini melihat bahwa biaya modal rata-rata tertimbang konstan berapapun tingkat hutang yang digunakan oleh perusahaan. Pertama, diasumsikan bahwa biaya hutang konstan seperti halnya dalam pendekatan laba bersih. Kedua, penggunaan hutang yang semakin besar oleh pemilik modal sendiri dilihat sebagai peningkatan risiko perusahaan. Oleh karena itu tingkat keuntungan yang diisyaratkan oleh pemilik modal sendiri akan meningkat sebagai akibat meningkatnya risiko perusahaan. Konsekwensinya biaya modal rata-rata tertimbang tidak mengalami perubahan dan keputusan struktur modal menjadi tidak penting.

3. Pendekatan tradisional (traditional approach). Pendekatan ini mengasumsikan bahwa hingga leverage tertentu, risiko perusahaan tidak mengalami perubahan. Sehingga baik tingkat bunga hutang maupun tingkat kapitalisasi relatif konstan. Namun demikian setelah leverage atau rasio hutang tertentu, biaya hutang dan biaya modal sendiri meningkat. Peningkatan biaya modal sendiri ini akan semakin besar dan bahkan akan lebih besar daripada penurunan biaya karena penggunaan hutang yang lebih murah.

Akibatnya biaya modal rata-rata tertimbang pada awalnya menurun dan setelah leverage tertentu akan meningkat. Ketiga pendekatan struktur modal tradisional ini pada mulanya dikembangkan oleh David Durand pada tahun 1952.

Kedua. Teori struktur modal modern yang terdiri dari:

1. Model Modigliani-Miller (MM) tanpa pajak. Pada tahun 1958 mereka mengajukan suatu teori yang ilmiah tentang struktur modal perusahaan. Teori mereka menggunakan beberapa asumsi: (a) Risiko bisnis perusahaan diukur dengan $\sigma$ EBIT (Standard Deviation 
Earning Before Interest and Taxes); (b) Investor memiliki pengharapan yang sama tentang EBIT perusahaan di masa mendatang; (c) Saham dan obligasi diperjual belikan di suatu pasar modal yang sempurna; (d) Seluruh aliran kas adalah perpetuitas (sama jumlahnya setiap periode hingga waktu tak terhingga). Dengan kata lain, pertumbuhan perusahaan adalah nol atau EBIT selalu sama.

2. Model Modigliani-Miller (MM) dengan pajak Pada tahun 1963, MM menerbitkan artikel sebagai lanjutan teori MM tahun 1958.Asumsi yang diubah adalah adanya pajak terhadap penghasilan perusahaan. Dengan adanya pajak ini, MM menyimpulkan bahwa penggunaan hutang akan meningkatkan nilai perusahaan karena biaya bunga hutang adalah biaya yang mengurangi pembayaran pajak.

3. Model Miller. Tahun 1976, Miller menyajikan suatu teori struktur modal yang juga meliputi pajak untuk pengasilan pribadi. Pajak pribadi ini adalah pajak penghasilan dari saham dan pajak pengasilan dari obligasi.

4. Financial distress dan agency costs. Financial distress adalah kondisi dimana perusahaan mengalami kesulitan keuangan dan terancam bangkrut. Jika perusahaan mengalami kebangkrutan, maka akan timbul biaya kebangkrutan yang disebabkan oleh: keterpaksaan menjual aktiva dibawah harga pasar, biaya likuidasi perusahaan, rusaknya aktiva tetap dimakan waktu sebelum terjual, dan sebagainya. Agency costs atau biaya keagenan adalah biaya yang timbul karena perusahaan menggunakan hutang dan melibatkan hubungan antara pemilik perusahaan (pemegang saham) dan kreditor. Biaya keagenan ini muncul dari problem keagenan. Jika perusahaan menggunakan utang, ada kemungkinan pemilik perusahaan melakukan tindakan yang merugikan kreditor.

5. Model trade off. Semakin besar penggunaan hutang, semakin besar keuntungan dari penggunaan hutang, tetapi PV biaya financial distress dan PV agency costs juga meningkat, bahkan lebih besar. Kesimpulannya adalah: penggunaan hutang akan meningkatkan nilai perusahaan tetapi hanya sampai kondisi tertentu.

6. Teori informasi tidak simetris. Awal dekade 1950-an, Gordon Donaldson dari Harvard University mengajukan teori tentang informasi asimetris. Asymmetric information adalah kondisi dimana suatu pihak memiliki informasi yang lebih banyak dari pihak lain. Karena asymmetric information, manajemen perusahaan tahu lebih banyak tentang perusahaan dibanding investor di pasar modal.

Pengertian Hutang. Hutang sering disebut juga sebagai kewajiban, dalam pengertian sederhana dapat diartikan sebagai kewajiban keuangan yang harus dibayar oleh perusahaan kepada pihak lain. Untuk menentukan suatu transaksi sebagai hutang atau bukan sangat tergantung pada kemampuan untuk menafsirkan transaksi atau kejadian yang menimbulkannya, seperti yang dikemukakan oleh FASB berikut ini dalam Statement of Financial Accounting Concept No.6 yang terdapat pada buku Chariri dan Ghozali (2007:157), yaitu "Hutang adalah pengorbanan manfaat ekonomi yang mungkin terjadi di masa yang mendatang yang mungkin timbul dari kewajiban sekarang dari suatu entitas untuk menyerahkan aktiva atau memberikan ke entitas lain dimasa mendatang sebagai akibat transaksi di masa lalu”. Munawir (2007:18) berpendapat bahwa "Hutang adalah semua kewajiban keuangan perusahaan kepada pihak lain yang belum terpenuhi, dimana hutang ini merupakan sumber dana atau modal perusahaan yang berasal dari kreditor", sedangkan Riyanto (2008:227), ”Hutang/modal asing adalah modal yang digunakan untuk membiayai kegiatan perusahaan yang berasal dari luar perusahaan yang sifatnya sementara bekerja di perusahaan, yang pada dasarnya harus dibayar kembali”. 
Berdasarkan definisi-definisi di atas dapat disimpulkan bahwa hutang adalah kewajiban keuangan perusahaan kepada pihak lain yang harus dibayar dengan uang, barang, atau jasa pada saat jatuh tempo.

Pengertian Debt to Equity Ratio. Debt Equity Ratio (DER) merupakan rasio solvabilitas yang digunakan untuk mengukur kemampuan modal sendiri perusahaan untuk dijadikan jaminan semua hutang perusahaan. Debt Equity Ratio (DER) merupakan rasio hutang yang digambarkan dengan perbandingan antara seluruh hutang, baik hutang jangka panjang maupun hutang jangka pendek dengan modal sendiri perusahaan(Ang : 2007:89). Semakin besar hutang, semakin besar risiko yang ditanggung perusahaan. Oleh sebab itu perusahaan yang tetap mengambil hutang sangat tergantung pada biaya relatif. Biaya hutang lebih kecil daripada dana ekuitas. Dengan menambahkan hutang ke dalam neracanya, perusahaan secara umum dapat meningkatkan profitabilitasnya, yang kemudian menaikkan harga sahamnya, sehingga meningkatkan kesejahteraan para pemegang saham dan membangun potensi pertumbuhan yang lebih besar. Sebaliknya biaya hutang lebih besar daripada dana ekuitas.

Debt to Equity Ratio (DER) merupakan perbandingan antara total hutang terhadap total shareholders equity yang dimiliki perusahaan. Total hutang disini merupakan total hutang jangka pendek dan total hutang jangka panjang. Sedangkan Shareholders Equity adalah total modal sendiri (total modal saham disetor dan laba ditahan) yang dimiliki oleh perusahaan.

Hutang jangka panjang dalam penelitian ini yang diukur adalah dengan menggunakan Debt To Equity Ratio. Rasio ini menggambarkan sampai sejauh mana modal dapat menutupi atau membayar hutang jangkapanjangnya kepada pihak luar (Munawir, 2007:263).

Perputaran Modal Kerja. Pada umumnya setiap perusahaan harus memiliki modal kerja yang cukup. Modal kerja itu sendiri adalah sejumlah dana yang terikat dalam unsur-unsur aktiva lancar dan hutang lancar untuk membiayai operasional sehari-hari yang pada umumnya akan berputar dalam periode tertentu. Adanya modal kerja yang cukup memudahkan perusahaan melakukan kegiatan usaha, tetapi apabila modal kerja kelebihan akan mengakibatkan sebagian dana yang tidak produktif. Hal ini akan mengurangi kesempatan perusahaan untuk memperoleh laba.

Menurut Sawir (2005:29), pengertian modal kerja adalah: "keseluruhan aktiva lancar yang dimiliki perusahaan atau dapat pula dimaksudkan sebagai dana yang harus tersedia untuk membiayai kegiatan operasi perusahaan sehari-hari”. Menurut Wild dan Subramanyam (2010:186) modal kerja merupakan "ukuran aktiva lancar yang penting yang mencerminkan pengamanan bagi kreditor dan untuk mengukur cadangan likuiditas yang tersedia untuk memenuhi kontinjensi dan ketidakpastian yang terkait dengan ketidakseimbangan antara arus kas masuk dan arus kas keluar”. Sedangkan definisi modal kerja menurut Rahardjo (2005:31) adalah "Jumlah aktiva lancar setelah dikurangi jumlah kewajiban lancar”.

Berdasarkan ketiga pendapat di atas, maka dapat disimpulkan bahwa modal kerja adalah aktiva lancar. Aktiva lancar ini merupakan dana atau asset yang digunakan untuk membiayai kegiatan operasi perusahaan sehari-hari.

Tujuan Manajemen Modal Kerja. Tujuan manajemen modal kerja adalah mengelola aktiva lancar dan hutang lancar sehingga diperoleh modal kerja yang layak dan menjamin 
tingkat likuiditas perusahaan. Konsep yang mendasari manajemen modal kerja yang sehat adalah dua keputusan yang menyangkut persoalan dasar perusahaan, yaitu tingkat investasi optimal dalam aktiva lancar dan perpaduan yang sesuai antara pendanaan jangka pendek dan pendanaan jangka panjang yang digunakan untuk mendukung investasi dalam aktiva lancar.Keputusan-keputusan tersebut mempengaruhi hasil yang diharapkan yaitu profitabilitas dan risiko yang dihadapi.

Menurut Abdul Raheman \& Mahamed (2007:12), dalam menentukan perputaran modal kerja, metode yang digunakan adalah: Metode Keterikatan atau Daur Dana dan Metode Perputaran Modal Kerja (Working Capital Turnover).

Penggunaan Modal Kerja. Penggunaan modal kerja akan menyebabkan perubahan bentuk maupun penurunan jumlah aktiva lancar yang dimiliki oleh perusahaan, tetapi penggunaan aktiva lancar tidak selalu diikuti dengan perubahannya atau turunnya jumlah modal kerja yang dimiliki oleh perusahaan. Penggunaan-penggunaan aktiva lancar yang mengakibatkan turunnya modal kerja adalah sebagai berikut: (1) Pembayaran biaya operasi-operasi perusahaan meliputi pembayaran upah, gaji, pembelian bahan atau barang dagangan, supplies kantor dan pembayaran biaya-biaya lainnya; (2) Kerugian-kerugian yang diderita oleh perusahaan karena adanya penjualan surat berharga atau efek, maupun kerugian yang insidentil lainnya; (3) Adanya pembentukan dana atau pemisahan aktiva lancar untuk tahun tertentu dalam jangka panjang, misalnya dana pelunasan obligasi, dana pensiun pegawai, dana expansi ataupun dana-dana lainnya; (4) Jangka panjang atau aktiva tidak lancar lainnya yang mengakibatkan berkurangnya aktiva lancar atau timbulnya utang lancar yang berakibat berkurangnya modal kerja; (5) Pembayaran kewajiban jangka panjang yang meliputi utang dalam bentuk hipotik, utang obligasi maupun bentuk utang jangka panjang lainnya, serta penarikan atau pembelian kembali (untuk sementara maupun untuk seterusnya) saham perusahaan yang beredar, atau adanya penurunan utang jangka panjang diimbangi berkurangnya aktiva lancar; (6) Pengambilan uang atau barang dagang atau pengambilan bagian keuntungan oleh pemilik perusahaan untuk kepentingan pribadinya (prive) dalam perusahaan perseorangan dan persekutuan atau adanya pembayaran deviden dalam perseroan terbatas.

PenelitianTerdahulu. (1) Marc Deloof (2003) melakukan penelitian terhadap 109 perusahaan non finansial di Belgia hasil penelitiannya mengemukakan manajemen modal kerja berpengaruh terhadap profitabilitas perusahaan, hal ini terlihat jika jumlah hutang meningkat berarti akan meningkatkan resiko keuangan dan apabila perusahaan tidak dapat mengelola dana dari hutang dengan baik akan berdampak negatif dan menurunkan profitabilitas. (2) Halim (2010), melakukan penelitian dengan judul "Analisis pengaruh Manajemen Modal Kerja dan Rasio Hutang terhadap Rentabilitas Ekonomi pada Industri Makanan dan Minuman di Bursa Efek Indonesia”. Hasil Penelitian menunjukkan bahwa : Working capital turnover memiliki pengaruh yang positif dan signifikan terhadap profitabilias perusahaan, meskipun tingkat signifikan tidak cukup tinggi. Working capital turnover hanya memiliki pengaruh terhadap profitabilias perusahaan dan Debt to total assets rasio berpengaruh negatif dan signifikan terhadap profitabilias perusahaan. Meskipun tingkat signifikannya lebih besar dari working capital turnover terhadap profitabilias perusahaan baik secara parsial maupun simultan. (3) Raheman dan Nasr (2007) menyatakan bahwa working capital turnover ratio berpengaruh positif signifikan terhadap tingkat profitabilitas perusahaan di Pakistan. Falope dan Ajilore (2009) hasil penelitian menemukan bahwa working capital turnover berpengaruh positif signifikan 
terhadap profitabilitas perusahaan di Nigeria. (4) Penelitian Nugraha (2009) hasil penelitiannya menyatakan bahwa variabel pendanaan modal kerja berkolerasi negatif signifikan terhadap profitabilitas dan penelitian Hanum (2008) menyatakan bahwa pendanaan modal kerja berpengaruh tidak signifikan terhadap profitabilitas. (5) Penelitian Khoirun Ni'mah (2010) tentang Pengaruh pengelolaan modal kerja dan debt to equity ratio (DER) terhadap return on investment perusahaan food and beverages yang terdaftar di BEI periode 2006-2008 hasil penelitian mengatakan bahwa kondisi Working Capital Turnover perusahaan mengalami penurunan dan hanya di tahun 2006 nilai WorkingCapital Turnover yang berada diatas nilai rata-rata. Kondisi Debt to Equity Ratio perusahaan dalam setiap tahunnya mengalami peningkatan. Pengaruh antar variabel menunjukkan bahwa hanya variabel Working Capital Turnover yang berpengaruh terhadap Return On Investment, sedangkan Current Ratio dan Debt to Equity ratio tidak berpengaruh terhadap Return On Investment.

Pengaruh Struktur Modal (Debt Equity Ratio) Terhadap Profitabilitas (ROA). Sumber pendanaan perusahaan dapat diperoleh melalui internal maupun eksternal perusahaan. Dana yang bersumber dari internal perusahaan, terkadang tidak cukup untuk memenuhi kebutuhannya. Oleh sebab itu, perusahaan dapat memperoleh dana yang bersumber dari eksternal perusahaan dengan cara hutang.

Besarnya pendanaan hutang dapat diukur dengan menggunakan Debt Equity Ratio, rasio ini digunakan untuk mengukur perbandingan antara total hutang dengan total aktiva. Artinya, seberapa besar aktiva perusahaan dibiayai oleh hutang atau seberapa besar hutang perusahaan berpengaruh terhadap pengelolaan aktiva. Marc Deloof (2003) mengemukakan manajemen modal kerja berpengaruh terhadap profitabilitas perusahaan, hal ini terlihat jika jumlah hutang meningkat berarti akan meningkatkan resiko keuangan dan apabila perusahaan tidak dapat mengelola dana dari hutang dengan baik akan berdampak negatif dan menurunkan profitabilitas.

Semakin besar nilai Debt to Equity Ratio (DER) menandakan bahwa struktur permodalan usaha lebih banyak memanfaatkan hutang- hutang relatif terhadap ekuitas. Semakin tinggi Debt to Equity Ratio (DER) mencerminkan risiko perusahaan yang relatif tinggi, hal tersebut dapat diduga ada pengaruh Debt to Equity Ratio (DER) terhadap profitabilitas perusahaan (ROA).

\section{Pengaruh Rasio Perputaran Modal Kerja (Working Capital Turnover Ratio)} Terhadap Profitabilitas (ROA). Rasio perputaran modal kerja merupakan perbandingan antara penjualan dengan jumlah keseluruhan aktiva lancar yang dimiliki suatu perusahaan pada suatu periode tertentu. (Abdul Raheman \& Mohamed, 2007:71), Semakin besar rasio perputaran modal kerja maka semakin baik suatu perusahan dimana persentase modal kerja yang ada mampu menghasilkan jumlah penjualan tertentu. Selain itu semakin besar rasio ini menunjukkan efektifnya pemanfaatan modal kerja yang tersedia dalam meningkatkan profitabilitas perusahaan.

Tingkat perputaran modal kerja yang tinggi akan menyenangkan kreditor jangka pendek. Mereka akan memperoleh kepastian bahwa modal kerja berputar dengan keceptan tinggi dan utang akan segera dapat dibayar meski dalam kondisi operasi yang sulit sehingga meningkatkan profitabilitas perusahaan. Suatu perusahaan dikatakan memiliki profitabilitas tinggi artinya bahwa modal yang besar, efektivitas juga akan tinggi. Tetapi modal yang besar belum tentu perusahaan memperoleh profitabilitas yang tinggi. Hal ini 
tergantung dari penggunaan modal kerja apakah efektif dan efisien atau tidak. Modal kerja yang selalu berputar akan mempengaruhi arus dana dalam perusahaan.

Apabila perputaran modal kerja mengalami peningkatan setiap tahunnya, berarti arus dana yang kembali ke perusahaan akan semakin lancar. Begitu pula sebaliknya, semakin rendah tingkat perputaran modal kerja, semakin panjang waktu terikatnya dana yang berarti pengelolaan modal kerja kurang efektif dan dan cenderung menurunkan profitabilitasnya.

Pengaruh Struktur Modal (Debt Equity Ratio) dan Rasio Perputaran Modal Kerja (Working Capital Turnover Ratio) Secara Bersama-sama Terhadap Profitabilitas (ROA). Semakin tinggi Debt to Equity Ratio (DER) mencerminkan risiko perusahaan yang relatif tinggi, jika perusahaan mempunyai penjualan yang stabil dapat menjamin hutang yang lebih besar secara bersama-sama penggunaan modal kerja lebih efektif dan efisien hal tersebut dapat diduga ada pengaruh Debt to Equity Ratio (DER) terhadap profitabilitas perusahaan (ROA), hal ini dikemukan oleh Halim (2010), Working capital turnover memiliki pengaruh yang positif dan signifikan dan Debt to total assets rasio berpengaruh negatif dan signifikan terhadap profitabilias perusahaan baik secara parsial maupun simultan

Berdasarkan kajian teori mengenai pengaruh hutang jangka panjang dan modal kerja rerhadap profitabilitas, penelitian ini memiliki desain kerangka pemikiran sebagai berikut :

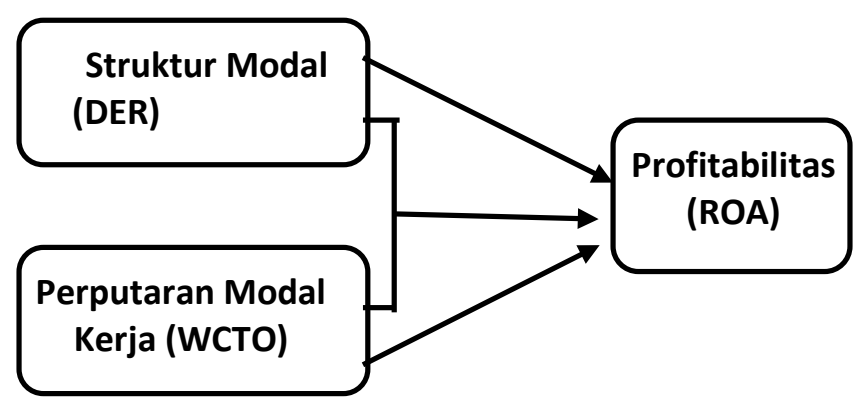

Gambar 1. Desain Kerangka Pemikiran

Hipotesis Penelitian. Berdasarkan kerangka berpikir yang telah diuraikan di atas maka hipotesis yang diajukan adalah sebagai berikut:

$\mathrm{H}_{1}$ : Terdapat pengaruh struktur modal terhadap profitabilitas pada perusahaan wajib pajak yang diperiksa oleh Kantor Pelayanan Pajak Madya Jakarta Pusat.

$\mathrm{H}_{2}$ : Terdapat pengaruh perputaran modal kerja terhadap profitabilitas pada perusahaan wajib pajak yang diperiksa oleh Kantor Pelayanan Pajak Madya Jakarta Pusat.

$\mathrm{H}_{3}$ : Terdapat pengaruh struktur modal dan perputaran modal kerja terhadap profitabilitas pada perusahaan wajib pajak yang diperiksa oleh Kantor Pelayanan Pajak Madya Jakarta Pusat. 


\section{METODE}

Dalam penelitian ini data yang digunakan adalah data sekunder (secondary data) yang berupa rasio keuangan antara lain Debt Equity Ratio (DER), Perputaran Modal Kerja (WCTO) sebagai variabel independen, dan Propitabilitas (ROA) sebagai variabel dependen pada periode tahun 2008 - 2012. Sumber data yang diambil oleh peneliti dan dibutuhkan dalam penelitian ini merupakan data sekunder (secondary data), yang diperoleh dari Kantor Pelayanan Pajak Madya Jakarta Pusat, serta data yang diambil melalui website Ditjen Pajak secara online. Selain itu terdapat data sekunder yang diambil dari Laporan Statistik Ekonomi Indonesia melalui perpustakaan Nasional serta perpustakaan Ditjen Pajak.

Dalam penelitian ini yang dijadikan populasi adalah perusahaan-perusahaan wajib pajak yang diperiksa oleh Kantor Pelayanan Pajak Madya Jakarta Pusat sektor usaha dagang sebanyak 150 perusahaan.

Sampel itu adalah sebagian dari populasi yang menjadi sumber data sebenarnya dalam suatu penelitian, dengan kata lain sampel adalah sebagian dari populasi untuk mewakili seluruh populasi yang karakteristiknya hendak diselidiki. Menurut Sugiyono (2008:73). Sampel dalam penelitian ini yang digunakan adalah 15 perusahaan wajib pajak yang bersumber dari Kantor Pelayanan Pajak Madya pada periode 2008 - 2012.

Teknik Pengambilan Sampel. Teknik sampling yang dipakai dalam penelitian ini menggunakan teknik purposive sampling, yaitu sampel yang akan diteliti sudah ditentukan dengan menggunakan batasan - batasan khusus yang sudah ditentukan sebelumnya. Kriteria untuk memilih sampel dalam penelitian ini ditentukan sebagai berikut: (1) Selalu melaporkan SPT dan tidak pernah terlambat membuat laporan SPT; (2) Merupakan perusahaan sejenis dalam industri yang sama; (3) Mempunyai likuiditas yang baik yaitu perusahaan yang mempunyai kemampuan untuk dapat membiayai kebutuhan jangka pendeknya dari aktiva lancarnya atau kelebihan aktiva lancar diatas hutang lancar selalu laba. Lokasi penelitian dilakukan pada Kantor Pelayanan Pajak Madya Jakarta Pusat. Adapun lamanya waktu penelitian adalah dari selama 30 hari.

Penentuan Model Yang Digunakan. Dalam regresi data panel dikenal tiga macam pendekatan (Gujarati,2008) yang terdiri dari pendekatan kuadrat terkecil (pooled least square), pendekatan efek tetap (fixed effect) dan pendekatan efek random (random effect Secara formal, ada tiga prosedur pengujian kesesuaian model yang akan digunakan untuk memilih model regresi data panel yang terbaik, yaitu 1) Uji Statistik F yang digunakan untuk memilih antara model common effect (CEM) atau model fixed effect (FEM) atau (Chow test); (2) Uji Lagrange Multiplier (LM) yang digunakan untuk memilih antara model common effect (CEM) atau model random effect (REM); (3) Uji Haussman yang digunakan untuk memilih antara model fixed effect (FEM) atau model random effect (REM).

\section{HASIL DAN PEMBAHASAN}

Data penelitian ini adalah perusahaan wajib pajak yang diperiksa oleh Kantor Pelayanan Pajak Madya pada periode 2008 - 2012 menggunakan sampel 15 perusahaan. Pada penelitian ini dilakukan pengujian terhadap temuan-temuan empiris mengenai pengaruh Debt to Equity Ratio (DER), dan Perputaran Modal Kerja (NWCTO) sebagai variabel 
independen terhadap Return On Asset (ROA), sebagai variabel dependen. Adapun distribusi sampel yang digunakan adalah sebagai berikut:

Tabel 1. Analisis Deskriptif Statistik Variabel Return On Asset (ROA), Debt to Equity Ratio (DER), dan Perputaran Modal Kerja (NWCTO)

\begin{tabular}{lccc}
\hline & ROA & DER & NWCTO \\
\hline Mean & 0.176043 & 0.936419 & 14.03669 \\
Median & 0.174193 & 0.763776 & 12.91331 \\
Maximum & 0.303136 & 2.907646 & 29.59725 \\
Minimum & 0.065574 & 0.114952 & 5.037568 \\
Std. Dev. & 0.049908 & 0.635170 & 5.915450 \\
Skewness & 0.532239 & 0.766278 & 0.800138 \\
Kurtosis & 3.441267 & 2.915081 & 2.913468 \\
& & & \\
Jarque-Bera & 4.149470 & 7.362316 & 8.026155 \\
Probability & 0.125590 & 0.251940 & 0.180780 \\
Sum & 13.20322 & 70.23140 & 1052.752 \\
Sum Sq. Dev. & 0.184323 & 29.85460 & 2589.449 \\
& & & \\
Observations & 75 & 75 & 75 \\
\hline
\end{tabular}

Analisis Penelitian Dengan Data Panel. Untuk mengetahui metode yang yang paling efisien dari tiga model persamaan yaitu Pooled least Squart (PLS), Fixed Effect Model (FEM) dan Random perlu diuji masing-masing tersebut dengan menggunakan metode regresi data panel, diperoleh model yang terbaik adalah Fixed Effect Model (FEM) untuk menentukan pengaruh Debt to Equity Ratio (DER), dan Perputaran Modal Kerja (NWCTO) terhadap Propitabilitas (ROA) perusahaan wajib pajak yang diperiksa oleh Kantor Pelayanan Pajak Madya Jakarta Pusat pada priode 2008-2012 seperti terlihat pada Tabel 2.

Berdasarkan hasil regresi (Tabel 2) menggunakan Fixed Effect Model (FEM) dapat dianalisis variabel independen terlihat, nilai konstanta $\mathrm{C}$ sebesar 0,072226 dengan nilai $\mathrm{t}$ hitung 4,980412 probabilita sebesar 0,0000 < 0,05 artinya konstanta C signifikan pada tingkat $\alpha=5 \%$, sedangkan variabel Debt to Equity Ratio (DER) mempunyai koefisien regresi sebesar $\quad-0.002932$ dengan nilai t-Statistik sebesar -3,884031, dengan probabilita sebesar 0,00000 < 0,05 artinya variabel Debt to Equity Ratio (DER) signifikan pada tingkat pada tingkat pada tingkat $\alpha=5 \%$ dan variabel Perputaran Modal Kerja (NWCTO) mempunyai koefisien regresi sebesar 0,007592, dengan nilai t-Statistik sebesar 9.018202 dengan probabilita sebesar 0,000 $<0,05$ artinya variabel Perputaran Modal Kerja (NWCTO) signifikan pada tingkat pada tingkat $\alpha=5 \%$. Persamaan regresi yang diestimasi secara simultan dilakukan pengujian dengan uji F diperoleh nilai $F_{\text {hitung }}$ sebesar 43.05410 dengan probability statistik $0,0000<0,05$, artinya secara simultan model ini signifikan dengan dengan nilai $\mathrm{R}^{2}$ sebesar 0,922342 . 
Tabel 2. Hasil Regresi Fixed Effect Model (FEM)

Dependent Variable: ROA

Method: Panel Least Squares

Date: 07/21/14 Time: $12: 12$

Sample: 20082012

Periods included: 5

Cross-sections included: 15

Total panel (balanced) observations: 75

\begin{tabular}{crrrr}
\hline \hline Variable & Coefficient & Std. Error & t-Statistic & Prob. \\
\hline \hline C & 0.072226 & 0.014502 & 4.980412 & 0.0000 \\
DER & -0.002932 & 0.007548 & -3.884031 & 0.0000 \\
NWCTO & 0.007592 & 0.000842 & 9.018202 & 0.0000 \\
\hline \hline
\end{tabular}

Effects Specification

Cross-section fixed (dummy variables)

\begin{tabular}{|c|c|c|c|}
\hline R-squared & 0.922342 & Mean dependent var & 0.176043 \\
\hline $\begin{array}{l}\text { Adjusted R- } \\
\text { squared }\end{array}$ & 0.900919 & S.D. dependent var & 0.049908 \\
\hline $\begin{array}{l}\text { S.E. of } \\
\text { regression }\end{array}$ & 0.015710 & Akaike info criterion & -5.272784 \\
\hline $\begin{array}{l}\text { Sum squared } \\
\text { resid }\end{array}$ & 0.014314 & Schwarz criterion & -4.747487 \\
\hline Log likelihood & 214.7294 & Hannan-Quinn criter. & -5.063039 \\
\hline F-statistic & 43.05410 & Durbin-Watson stat & 1.733953 \\
\hline Prob(F-statistic) & 0.000000 & & \\
\hline
\end{tabular}

Uji Estimasi Model. Dari tiga model, yaitu Model Common Effect (pooled least square), Fixed Effect Model (FEM), atau Rand om Effect Model (REM) yang cocok digunakan melakukan estimasi, maka harus dilakukan beberapa pengujian antara lain:

Uji $\boldsymbol{F}$ Restricted. Dengan menggunakan uji $F$ Restricted diperoleh hasi hitung nilai $F_{\text {tabel }}=$ 17,4712

$F_{\text {hitung }}>F_{\text {tabel }}$, dengan $\alpha=5 \%, 17,4712>8,571$ maka Fixed Effect Model (FEM) lebih tepat untuk digunakan model estimasi persamaan regresi dibandingkan dengan Common Effect Model (pooled least square) .

Uji Haussman. Uji Haussman digunakan untuk memilih pendekatan terbaik antara model pendekatan Fixed Effect Model (FEM) dan Random Effect Model (REM).

Dengan kriteria pengujian hipotesis:

Jika $\chi^{2}$ hitung $\geq \chi^{2}$ tabel dan $p$-value signifikan, maka $\mathrm{H}_{\mathrm{a}}$ diterima, artinya model FEM lebih tepat digunakan (Aulia, 2004:31) 
Tabel 3. Hasil Uji Hausman

Test cross-section random effects

\begin{tabular}{llll}
\hline \hline Test Summary & $\begin{array}{l}\text { Chi-Sq. } \\
\text { StatisticChi-Sq. }\end{array}$ & d.f. & Prob. \\
\hline \hline $\begin{array}{l}\text { Cross-section } \\
\text { random }\end{array}$ & 11.395285 & 2 & 0.0000
\end{tabular}

Berdasarkan Tabel 3 Haussman test for fixed effect versus random effect di atas, diperoleh $\chi_{\text {hitung }}^{2}=11,395285<\chi_{\text {tabel }}^{2}=8,57$ dan $p$-value $=0,0000$, maka $\chi^{2}$ hitung $>\chi_{\text {tabel }}^{2}$ signifikan pada $\alpha=5 \%$, artinya hipotesis $\quad \mathrm{H}_{\mathrm{a}}$ : Fixed Effect Model (FEM) diterima atau pendekatan model yang terbaik adalah Fixed Effect (FEM). Dari tiga hasil pengujian model estimasi di atas, maka dapat ditentukan bahwa model yang terbaik adalah Fixed Effect Model (FEM) untuk menentukan pengaruh Debt to Equity Ratio (DER), dan Perputaran Modal Kerja (NWCTO) terhadap Propitabilitas (ROA) perusahaan wajib pajak yang diperiksa oleh Kantor Pelayanan Pajak Madya Jakarta Pusat pada priode 2008 2012. Untuk itu tidak perlu lagi melakukan UjiLagrange Multiplier (LM) karena uji $F$ Restricted telah menunjukkan FEM lebih baik dari pada Common Effect Model (pooled least square), dan sebaliknya FEM lebih baik daripada REM.

Hasil Estimasi Model. Model estimasi yang digunakan adalah data panel dengan menggunakan metode Fixed Effect Model (FEM), maka model persamaan regresi dapat dituliskan sebagai berikut:

ROA $=0,072226-0,002932 *$ DER $+0,007592 *$ NWCTO $+[C X=F]$

Hasil estimasi dapat diinterprestasikan sebagai berikut: Pertama. Dari persamaan hasil regresi di atas dapat dijelaskan bahwa nilai konstanta sebesar 0,072226 artinya ketika variabel-variabel independen bernilai nol, maka nilai Propitabilitas (ROI) adalah sebesar 0,072226. Kedua. Nilai koefisien regresi variabel Debt Equity Ratio (DER) sebesar 0,002932, yang artinya terdapat pengaruh negatif variabel Debt Equity Ratio (DER) terhadap variabel Propitabilitas (ROA) dimana setiap kenaikan Debt Equity Ratio (DER) sebesar $1 \%$ akan menurunkan Propitabilitas (ROI) sebesar 0,002932 \%. Nilai t-Statistik sebesar -3,884031 dengan probability adalah 0,000 < 0,05 menunjukkan bahwa variabel Hutang jangka panjang yang diproksikan dengan Debt Equity Ratio (DER) berpengaruh negatif dan signifikan terhadap variabel Propitabilitas (ROA). Hal ini berarti jika terjadi peningkatan Debt Equity Ratio (DER) yang ditunjukkan oleh hutang bertambah akan menurunkan Propitabilitas (ROA), hal ini berimplikasi bahwa perusahaan harus dapat menjaga keseimbangan hutang yang digunakan untuk investasi yang ahkirnya dapat meningkatkan equity (modal sendiri) yang diperoleh dari laba yang ditahan. Ketiga. Nilai koefisien regresi variabel Perputaran Modal Kerja (NWCTO) sebesar 0,007592 artinya terdapat pengaruh variabel secara positif dan signifikan terhadap variabel Propitabilitas (ROA), dimana setiap terjadi kenaikan Perputaran Modal Kerja (NWCTO) 1 kali akan menaikkan Propitabilitas (ROI) sebesar 0,007592 \%. Nilai t-Statistik sebesar 9,018202, 
dengan probability adalah 0,0000 $<0,05$, hal ini menunjukkan bahwa Perputaran Modal Kerja (NWCTO) signifikan berpengaruh positif terhadap variabel Propitabilitas (ROA). Hal ini menunjukan bahwa jika Perputaran Modal Kerja (NWCTO) naik akan dapat meningkatkan nilai Propitabilitas (ROA), jika manajemen mampu menurunkan hutang jangka pendeknya dan meningkatkan aktiva lancarnya pada akhirnya dapat meningkatkan Propitabilitas (ROI) hal ini disebabkan beban utang perusahan menurun, seperti turunnya beban bunga pinjaman. Keempat. Persamaan dapat diestimasi secara simultan dengan melakukan pengujian dengan cara membandingkan nilai $F_{\text {hitung }}$ dengan $F_{\text {tabel }}$. Syarat hipotesis dapat diterima apabila $F_{\text {hitung }} \geq F_{\text {tabel }}$. Berdasarkan pada uji hipotesis tabel di atas diperoleh nilai Fhitung sebesar 43.05410 dengan $\alpha=5 \%$ dan derajat kebebasan 73 (df=752) diperoleh nilai Ftabel sebesar 8,571. Hal ini berarti hipotesis yang menyatakan bahwa secara simultan variabel bebas Debt to Equity Ratio (DER), dan Perputaran Modal Kerja (NWCTO) berpengaruh secara signifikan terhadap Propitabilitas (ROA) perusahaanperusahaan wajib pajak yang diperiksa oleh Kantor Pelayanan Pajak Madya Jakarta Pusat sektor usaha dagang pada priode 2008 - 2012.

Uji Normalitas Data. Uji ini bertujuan untuk menguji apakah dalam model regresi berganda variabel bebas dan terikat akan berdistribusi secara normal atau tidak untuk itu perlu diuji dengan metode Jarque-Bera (J-B) dari masing-masing variabel.

Hasil uji variabel Propitabilitas (ROA) diperoleh nilai sebesar 4,149470 dengan probability 0,125590 >0,05 artinya data dari variabel Propitabilitas (ROA) berdistribusi secara normal. Secara Grafik dapat dilihat distribusi data dari variabel Propitabilitas (ROA) dari masing-masing perusahaan-perusahaan wajib pajak yang diperiksa oleh Kantor Pelayanan Pajak Madya Jakarta Pusat sektor usaha dagang priode 2008 - 2012 pada gambar berikut:

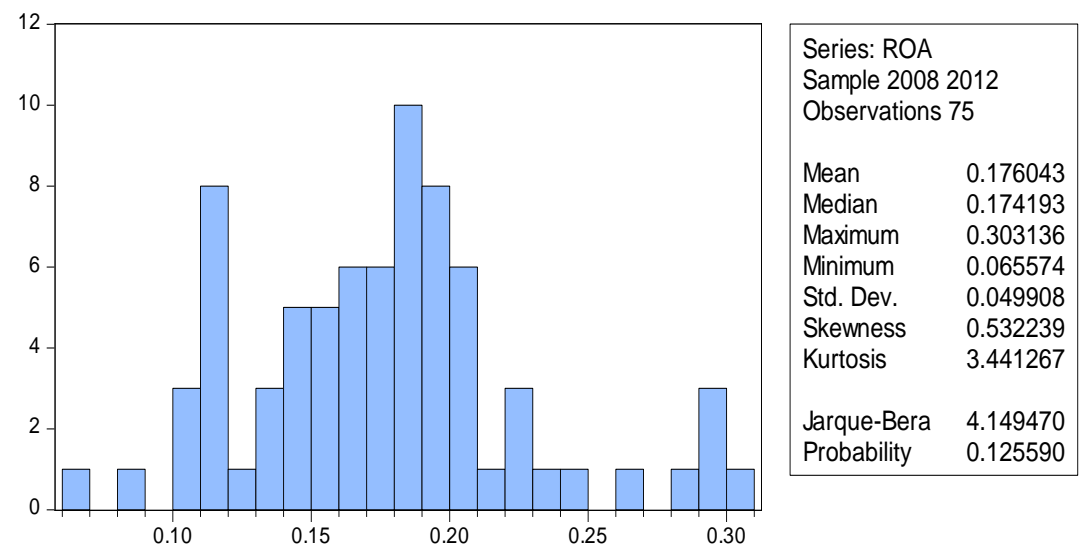

Gambar 2. Distribusi Data Propitabilitas (ROA) Periode 2008 - 2012 Sumber: Data Sekunder diolah dengan E View

Hasil uji untuk variabel Debt Equity Ratio (DER) berdistribusi normal ini terlihat dari nilai Jarque-Bera se-besar 7,362316 dengan probability 0,251940 $>0,05$ artinya data dari variabel Debt Equity Ratio (DER) berdistribusi secara normal. Secara Grafik dapat dilihat distribusi data dari variabel Debt Equity Ratio (DER) dari masing-masing perusahaan-perusahaan wajib pajak yang diperiksa oleh Kantor Pelayanan Pajak Madya Jakarta Pusat sektor usaha dagang priode 2008 - 2012 pada gambar berikut: 


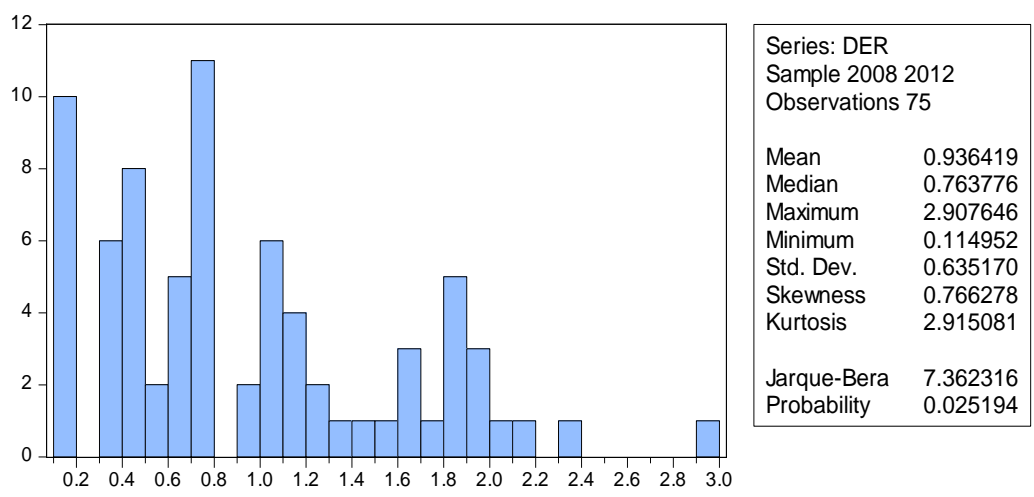

Gambar 3. Distribusi Data Debt to Equity Ratio (DER) Periode 2008 - 2012 Sumber: Data Sekunder diolah dengan E View

Hasil uji untuk variabel Perputaran Modal Kerja (NWCTO) berdistribusi normal ini terlihat dari nilai Jarque-Bera sebesar 8,026155 dengan probability 0,18078. Secara Grafik dapat dilihat distribusi distribusi data dari variabel Perputaran Modal Kerja (NWCTO) dari masing-masing perusahaan-perusahaan wajib pajak yang diperiksa oleh Kantor Pelayanan Pajak Madya Jakarta Pusat sektor usaha dagang priode 2008 - 2012 pada gambar berik

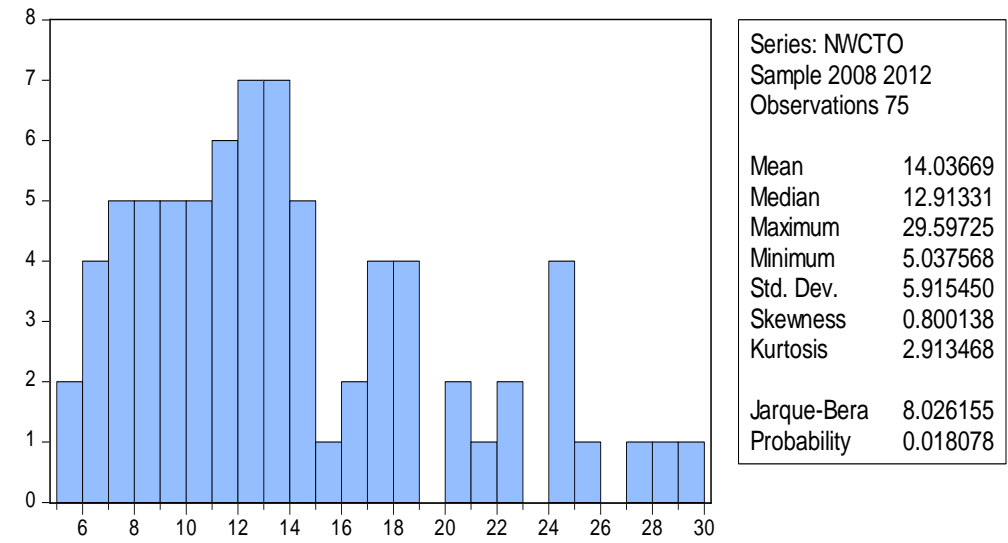

Gambar 4. Distribusi Data Perputaran Modal Kerja (NWCTO) Periode 2008 - 2012 Sumber: Data Sekunder diolah dengan E View

Uji Multikoloneritas. Kolinieritas antar variabel dapat diidentifikasi dengan menggunakan nilai korelasi parsial antar variabel independen jika nilai korelasi lebih besar dari 0,80 diidentifikasi ada masalah multikoloneritas. Dari hasil perhitungan nilai korelasi parsial antar vatiabel dapat dilihat pada tabel berikut ini:

Tabel 4. Hasil Perhitungan Matrix Correlation

\begin{tabular}{lccr}
\hline & ROA & DER & NWCTO \\
\hline ROA & 1.00000 & -0.52807 & 0.770791 \\
DER & -0.52807 & 1.00000 & -0.659023 \\
NWCTO & 0.770791 & -0.659023 & 1.000000 \\
\hline
\end{tabular}


Dari tabel diatas hasil nilai korelasi antar variabel kurang dari 0,80 dapat diidentifikasi tidak ada masalah multikoloneritas.

Uji Heterokedastisitas. Dengan uji Park dapat diidentifikasi masalah heterokedastisitas dari hasil perhitungan dapat diidentifikasi tidak ada heterokedastisitas karena nilai koefisien regresi variabel independen tidak signifikan terhadap Dependent Variable: $\operatorname{RESID}^{\wedge} 2$ dapat dilihat pada tabel berikut ini:

Tabel 5. Hasil Pengujian Heterokedastisitas Dengan Uji White

Heteroskedasticity Test: White

\begin{tabular}{llll}
\hline \hline F-statistic & 0.771693 & Prob. F(5,74) & 0.5732 \\
Obs*R-squared & 3.964595 & Prob. Chi- Sq(5) & 0.5545 \\
Scaled explained SS & 2.230442 & Prob. Chi-Sq(5) & 0.8164 \\
\hline \hline
\end{tabular}

Test Equation:

Dependent Variable: RESID^2

Method: Least Squares

Date: 07/21/14 Time: 04:01

Sample: 75

Included observations: 75

\begin{tabular}{crrrr}
\hline \hline Variable & Coefficient & Std. Error & t-Statistic & Prob. \\
\hline \hline C & -0.001153 & 0.002240 & -0.514536 & 0.6084 \\
DER & 0.000916 & 0.001970 & 0.465023 & 0.6433 \\
DER^2 & -0.000181 & 0.000444 & -0.406980 & 0.6852 \\
DER*NWCTO & $-4.56 E-07$ & $8.72 E-05$ & -0.005226 & 0.9958 \\
NWCTO & 0.000182 & 0.000207 & 0.878711 & 0.3824 \\
NWCTO^2 & $-4.35 E-06$ & $4.79 E-06$ & -0.908077 & 0.3668 \\
\hline \hline R-squared & 0.049557 & Mean dependent var & 0.00100 \\
Adjusted R-sq & -0.014662 & S.D. dependent var & -10.679 \\
S.E. of regres & 0.001120 & Akaike info criterion & -10.501 \\
Sum sq resid & $9.28 E-05$ & Schwarz criterion & -10.608 \\
Log likelihood & 433.1848 & Hannan-Quinn criter. & 0.92665 \\
F-statistic & 0.771693 & Durbin-Watson stat & \\
Prob(F-statistic) & 0.573178 & & \\
\hline
\end{tabular}

Uji Autokorelasi. Tujuan melakukan uji autokorelasi untuk mendeteksi autokorelasi, dapat dilakukan uji statistik melalui uji Durbin-Watson (DW test). Dari tabel 4.7. diperoleh nilai Durbin-Watson (DW test) sebesar 1,733953 dimana nilai D-W berada $1,654<1,733953<4-1,654$, dapat disimpulkan bahwa tidak terjadi problem autokorelasi.

Koefisien Determinasi. Koefisien determinasi $\mathrm{R}^{2}$ berujuan untuk mengetahui kemampuan penjelas (incremental explanatory power) dari masing-masing variabel penjelas (independen) yang digunakan dalam penelitian ini menghasilkan nilai sebesar 0,922342, ini menunjukkan kontribusi variabel Debt Equity Ratio (DER), dan Perputaran Modal 
Kerja (NWCTO) dapat menjelaskan hubungannya dengan Propitabilitas (ROA) perusahaan-perusahaan wajib pajak yang diperiksa oleh Kantor Pelayanan Pajak Madya Jakarta Pusat sektor usaha dagang sebesar 92,2342 \%, sedangkan sisanya sebesar 7,7658 \% dijelaskan oleh variabel lain yang tidak masuk dalam model, berarti bahwa hubungan antara variabel Debt Equity Ratio (DER), dan Perputaran Modal Kerja (NWCTO) dengan Propitabilitas (ROA) sangat kuat .

Berdasarkan pengujian hipotesis yang telah dilakukan dengan mengunakan variabel indipenden Debt Equity Ratio (DER), dan Perputaran Modal Kerja (NWCTO) terhadap Propitabilitas (ROA) perusahaan-perusahaan wajib pajak yang diperiksa oleh Kantor Pelayanan Pajak Madya Jakarta Pusat sektor usaha dagang priode 2008 - 2012 dengan menggunakan program E Views dengan data panel maka dapat ditentukan bahwa model yang terbaik adalah Fixed Effect Model (FEM).

Pengaruh Struktur Modal (Debt Equity Ratio) terhadap Propitabilitas (ROA) Secara Parsial. Hasil uji regresi secara parsial menunjukkan pengaruh Debt Equity Ratio (DER) terhadap Propitabilitas (ROA) perusahaan-perusahaan wajib pajak yang diperiksa oleh Kantor Pelayanan Pajak Madya Jakarta Pusat sektor usaha dagang menunjukan pengaruh yang signifikan terlihat dari hasil uji t hitung sebesar -3,884031 dengan probabilita sebesar $0,0000>0,05$, dari hasil penelitian persamaan regresi diatas terlihat bahwa koefisien regresi untuk variabel Debt Equity Ratio (DER) bernilai negatif sebesar 0,002932, artinya variabel Propitabilitas (ROA) berpengaruh negatif dan signifikan, hasil penelitian ini relevan dengan hasil penelitian Shahib Natarsyah (2010) menemukan bahwa Debt to Equity Ratio (DER) mempunyai pengaruh negatif dan signifikan terhadap Propitabilitas (ROI) dan Khoirun Ni'mah (2010) mengatkan Pengaruh antar variabel menunjukkan bahwa hanya variabel Working Capital Turnover yang berpengaruh terhadap Return On Asset, sedangkan Current Ratio dan Debt to Equity ratio tidak berpengaruh terhadap Return On Investment, hal ini bertentangan dengan penelitian ini bahwa kenaikan DER dapat mempengaruhi Profitabilitas (ROA), karena beban hutang yang bertambah diakibatkan karena jumlah hutang bertambah sedangkan Equity perusahaan tidak meningkat, hal ini akan menurunkan ROA tetapi peneliti lainnya mendukung penelitian ini antara lain: Nugraha (2009) menyatakan bahwa variabel pendanaan modal kerja yang diperoleh dari hutang jangka panjang yang diproksikan dengan DER berkolerasi negatif signifikan terhadap profitabilitas dan penelitian Hanum (2008) menyatakan bahwa pendanaan modal Kerja berpengaruh tidak signifikan terhadap profitabilitas. Berbeda dengan Utwal (2011) bahwa pendanaan modal kerja yang diproksikan dengan DER berpengaruh secara negatif signifikan terhadap profitabilitas (ROA) perusahaan. Dapat disimpulkan bahwa Struktur Modal (Equity Ratio) berpengaruh megatif dan signifikan terhadap Profitabilitas (ROA).

\section{Pengaruh Perputaran Modal Kerja (NWCTO) terhadap Profitabilitas (ROA) \\ Secara Parsial. Hasil uji regresi secara parsial menunjukkan pengaruh Perputaran Modal Kerja (NWCTO) terhadap Profitabilitas (ROA) perusahaan-perusahaan wajib pajak yang diperiksa oleh Kantor Pelayanan Pajak Madya Jakarta Pusat sektor usaha dagang menunjukan pengaruh positif dan signifikan terlihat dari hasil uji t yang dilakukan diperoleh nilai t hitung sebesar 9,018202 dengan probabilita sebesar 0,0000 $<0,05$, dari hasil penelitian persamaan regresi diatas terlihat bahwa koefisien regresi untuk variabel Perputaran Modal Kerja (NWCTO) bernilai positif sebesar 0,007592, artinya Perputaran}


Modal Kerja (NWCTO) secara parsial perpengaruh positif dan signifikan terhadap Profitabilitas (ROA) perusahaan-perusahaan wajib pajak yang diperiksa oleh Kantor Pelayanan Pajak Madya Jakarta Pusat sektor usaha dagang, hasil penelitian ini relevan dengan penelitian Halim (2010) Working capital turnover memiliki pengaruh yang positif dan signifikan terhadap rentabilitas ekonomi, meskipun tingkat signifikan tidak cukup tinggi. Working capital turnover hanya memiliki pengaruh sebesar $0.1 \%$ terhadap rentabilitas ekonomi perbedaan dengan penelitian ini adalah variabel dependennya yang digunakan pada penelitian ini adalah Profitabilitas (ROA).

Dapat disimpulkan bahwa Perputaran Modal Kerja (NWCTO) berpengaruh positif dan signifikan terhadap Profitabilitas (ROA), hal ini dapat dilihat dengan makin sering Perputaran Modal Kerja ditandai dengan meningkatnya penjualan dengan asumsi bahwa hutang berkurang akan dapat menekan biaya beban utangnya dan pada akhirnya dapat meningkatkan Profitabilitas.

Pengaruh Struktur Modsl (Debt to Equity Ratio), dan Perputaran Modal Kerja (NWCTO) terhadap Profitabilitas (ROA) Secara Bersama-sama (Simultan). Hasil uji regresi secara simultan menunjukkan pengaruh Struktur Modl (Debt to Equity Ratio), dan Perputaran Modal Kerja (NWCTO) terhadap Profitabilitas (ROA) perusahaanperusahaan wajib pajak yang diperiksa oleh Kantor Pelayanan Pajak Madya Jakarta Pusat sektor usaha dagang priode 2008 - 2012, dengan melakukan uji F diperoleh $F_{\text {hitung }}$ sebesar 43,05410, dengan $\alpha=5 \%$ dan derajat kebebasan $73(\mathrm{df}=75-2)$ diperoleh nilai $F_{\text {tabel }}$ sebesar 8,571, hal ini menunjukan bahwa model persamaan regresi dapat estimasi dengan data panel dengan menggunakan metode Fixed Effect Model (FEM), dapat dituliskan sebagai berikut:

$$
\text { ROA }=0,072226-0,002932 * \text { DER }+0,007592 * \text { NWCTO }+\lceil C X=F 1
$$

Persamaan regresi ini dapat digunakan untuk melakukan peramalan (porecasting) terhadap nilai variabel return saham dapat digambarkan dengan grafik berikut ini:
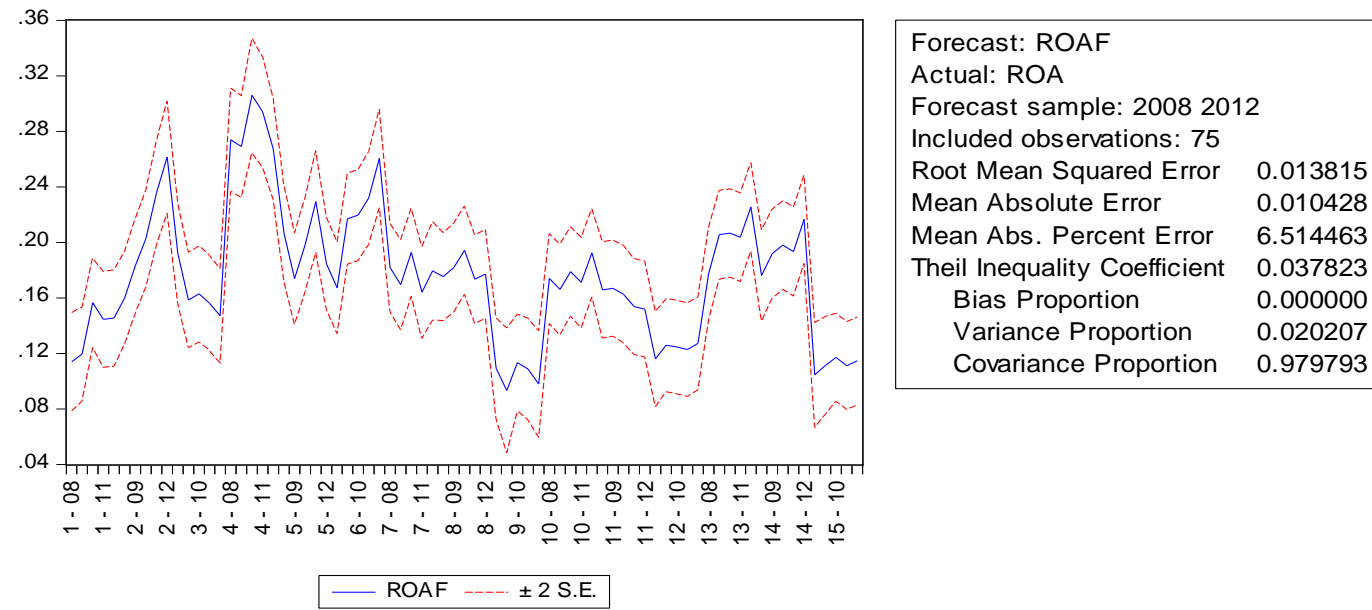

Gambar 5. Grafik Peramalan (Forecasting) Profitabilitas (ROA) perusahaan-perusahaan wajib pajak yang diperiksa oleh Kantor Pelayanan Pajak Madya Jakarta Pusat Sumber: www.idx.com. Data diolah 
Dari model persamaan regresi diatas dengan menggunakan data panel Fixed Effect Model (REM) dapat menentukan pengaruh Struktur Modal (Debt to Equity Ratio), dan Perputaran Modal Kerja (NWCTO) terhadap Profitabilitas (ROA) perusahaan-perusahaan wajib pajak yang diperiksa oleh Kantor Pelayanan Pajak Madya Jakarta Pusat sektor usaha dagang secara simultan pada 15 perusahaan dapat diramalkan jika terjadi kenaikan nilai Debt to Equity Ratio (DER) sebesar $1 \%$ akan mengakibatkan Profitabilitas (ROA) turun sebesar 0,002932 \% dengan asumsi variabel Perputaran Modal Kerja (NWCTO) tetap (cataris paribus) dan jika variabel Perputaran Modal Kerja (NWCTO) naik $1 \%$ akan mengakibatkan Profitabilitas (ROA) naik sebesar 0,007592 \% dengan asumsi variabel Debt to Equity Ratio (DER) tetap (cataris paribus).

\section{PENUTUP}

Simpulan. Berdasarkan hasil penelitian dan pembahasan dengan hasil regresi menggunakan 3 model pendekatan Pooled Least Square (PLS), Fixed Effect Model (FEM) dan Random Effect Model (REM) dapat disimpulkan bahwa Fixed Effect Model (FEM) dianggap sebagai model yang terbaik untuk mengestimasi pengaruh Struktur Modal (Debt to Equity Ratio) dan Perputaran Modal Kerja (NWCTO) terhadap Profitabilitas (ROA) perusahaan-perusahaan wajib pajak yang diperiksa oleh Kantor Pelayanan Pajak Madya Jakarta Pusat sektor usaha dagang periode tahun 2008 - 2012.

Berdasarkan hasil penelitian dan pembahasan, dapat disimpulan sebagai berikut: (1) Struktur Modal (Debt to Equity Ratio) berpengaruh negatif dan signifikan terhadap Profitabilitas (ROA) perusahaan-perusahaan wajib pajak yang diperiksa oleh Kantor Pelayanan Pajak Madya Jakarta Pusat sektor usaha dagang periode tahun 2008 - 2012 dengan hasil uji t hitung sebesar $-3,884031$ dengan probabilita sebesar 0,0000 $>0,05$, dengan tingkat signifikasi pada $\alpha=5 \%$ dan mempunyai nilai koefisien regresi secara parsial sebesar -0,002932, dapat disimpulkan bahwa variabel Struktur Modal (Debt to Equity Ratio) berpengaruh negatif dan signifikan terhadap Profitabilitas (ROA) perusahaan-perusahaan wajib pajak yang diperiksa oleh Kantor Pelayanan Pajak Madya Jakarta Pusat sektor usaha dagang periode tahun 2008 - 2012 artinya hipotesis pertama diterima. (2) Perputaran Modal Kerja (NWCTO) berpengaruh positif dan signifikan terhadap Profitabilitas (ROA) perusahaan-perusahaan wajib pajak yang diperiksa oleh Kantor Pelayanan Pajak Madya Jakarta Pusat sektor usaha dagang periode tahun 2008 2012 dengan hasil uji t hitung sebesar 9,018202 dengan probabilita sebesar 0,0000< 0,05 , dengan tingkat signifikasi pada $\alpha=5 \%$ dan mempunyai nilai koefisien regresi secara parsial sebesar 0,007592, dapat disimpulkan bahwa Perputaran Modal Kerja (NWCTO) berpengaruh positif dan signifikan terhadap Profitabilitas (ROA) perusahaan-perusahaan wajib pajak yang diperiksa oleh Kantor Pelayanan Pajak Madya Jakarta Pusat sektor usaha dagang periode tahun 2008 - 2012 artinya hipotesis kedua diterima. (3) Struktur Modal (Debt to Equity Ratio), dan Perputaran Modal Kerja (NWCTO) secara bersama-sama berpengaruh signifikan terhadap Profitabilitas (ROA) perusahaan-perusahaan wajib pajak yang diperiksa oleh Kantor Pelayanan Pajak Madya Jakarta Pusat sektor usaha dagang priode 2008 - 2012, dengan hasil uji $\mathrm{F}$ hitung sebesar 43,05410, tingkat signifikansi sebesar $0,000<0,05$ dengan tingkat signifikasi pada $\alpha=5 \%$, secara statistik semua variabel yang diteliti berpengaruh signifikan terhadap Profitabilitas (ROA) perusahaan-perusahaan wajib pajak yang diperiksa oleh Kantor Pelayanan Pajak Madya Jakarta Pusat sektor usaha dagang priode 2008 - 2012, sedangkan nilai R-square sebesar 0,922342, ini menunjukkan 
kontribusi Debt to Equity Ratio (DER), dan Perputaran Modal Kerja (NWCTO) yang dapat menjelaskan hubungannya dengan Profitabilitas (ROA) perusahaan-perusahaan wajib pajak yang diperiksa oleh Kantor Pelayanan Pajak Madya Jakarta Pusat sektor usaha dagang periode 2008 - 2012 sebesar 92,2342 \% sedangkan sisa sebesar 7,766\%, dijelaskan oleh variabel lain yang tidak masuk dalam model.

Berdasarkan hasil analisis regresi menunjukkan bahwa semua hipotesis yang diajukan dalam penelitian ini dapat diterima secara stastistik terlihat dari semua variabel independen berpengaruh terhadap variabel dependen secara signifikan.

Saran. Berdasarkan kesimpulan di atas peneliti mencoba memberikan usulan saran sebagai berikut: (1) Untuk menjaga stabilitas kegiatan operasional perusahaan-perusahaan wajib pajak yang diperiksa oleh Kantor Pelayanan Pajak Madya Jakarta Pusat sektor usaha dagang disarankan agar menjaga keseimbangan hutang jangka panjang maupun jangka pendek terhadap Equity perusahaan sehingga Debt to Equity Ratio (DER) tidak selalu meningkat dan jika menambah hutang dengan tujuan investasi harus dapat meningkatkan laba yang diperoleh melalui peningkatan kinerja keuangan perusahaan masing-masing. (2) Agar selalu menjaga Struktur Modal yang optimal sampai titik tertentu sehingga dapat meningkatkan laba tercermin dari Profitabilitas (ROA) perusahaan harus meningkatkan penjualan sejalan dengan meningkatnya Perputaran Modal Kerja (NWCTO) dengan menurunkan selisih antara aktiva lancar dengan huatang lancar. (3) Untuk menjaga stabilitas kegiatan operasional perusahaan-perusahaan wajib pajak yang diperiksa oleh Kantor Pelayanan Pajak Madya Jakarta Pusat sektor usaha dagang disarankan agar menjaga kesimbangan antara penambahan antara hutang dengan peningkatan laba sehingga Debt to Equity Ratio (DER) terjaga kestabilannya serentak dengan peningkat perputaran modal kerja dengan meningkatnya penjualan dan akhirnya dapat meningkatkan laba. (4) Peneliti lainnya jika akan melakukan penelitian sejenis agar menambah variabel independen, seperti Net Profit Margin (NPM), Debt to Total Asset (DTA), Operating Profit Margin (OPM) dan variabel yang relevan dengan tujuan penelitian, memperpanjang waktu penelitian sehingga dapat diperoleh informasi secara berkesinambungan.

\section{DAFTAR RUJUKAN}

Abdul Raheman \& Mohamed Nasr. (2007) "Working Capital Management and Profitability - Case of Pakistani Firms”. International of Business Research Papers. Vol.3 (1) March 2007. pp. 279 - 300.

Ang, Robert, (2007) Buku Pintar Pasar Modal Indonesia, Jakarta :Mediasoft

Brigham, Eugene F and Joel F. Houston. (2006) Dasar-dasar Manajemen Keuangan, Edisi kesepuluh (buku1). Jakarta : PT. Salemba Empat.

Brigham, E and Daves,P. (2010) Intermediate Financial Management. Tenth Edition. South - Western: Cengage Learning.

Brigham,Eugene, Michael C, Ehrhardt, (2005) Financial Management Theory And Practice. $11^{\text {th }}$ South - Western: Thomson

Fredy Rangkuti, (2007) Manajemen Persediaan: Aplikasi di Bidang Bisnis, Jakarta: Raja Grafindo Persada.

Gitman, Lawrence J. (2009) Principle Of Managerial finance, Twelfth Edition,USA: Prentice Hall.

Gujarati, Damodar, (2008) Basic Econometrics, 3nd Edition, McGraw-Hill, Inc,Singapore 
Hanun, E. L. (2008) "Pengaruh Kebijakan Modal Kerja terhadap Return On Investment pada Industry Rokok yang terdaftar di Bursa Efek Indonesia”, Tesis, Medan: Program Pascasarjana USU

Harahap, Sofyan Safri, (2001) Analisis Kritis Atas Laporan Keuangan, Jakarta: Penerbit Raja Grafindo Persada.

Husnan, Suad dan Pudjiastuti, Enny. (2006) Dasar-dasar Manajemen Keuangan, Yogyakarta: UPP AMP YKPN

Lukman Syamsuddin, (2007) Manajmen Keuangan Perusahaan: Konsep Aplikasi Dalam Perencanaan, Pengawasan, Dan Pengambilan Keputusan. Jakarta: Raja Grafindo Persada.

Mathuva, D. M. (2009) "The Influence of Working Capital Management Components on Corporate Profitability”, Journal Economic Sciences Series, 1(36), pages 272-277, Available from: URL: http://www.Ssm.Com.

Munawir, S, (2007) Analisa Laporan Keuangan, Edisi 4, Cetakan 13, Yogyakarta: Liberty.

Nugraha, M. (2009) “Analisis Kebijakan Modal Kerja dan Pengaruhnya terhadap Profitabilitas Hotel Dyana Pura Denpasar”, Tesis, Bali: Program Pascasarjana UNUD

Riyanto, Bambang. (2008) Dasar-dasar Pembelanjaan Perusahaan, Yogyakarta, Edisi keempat, Yogyakarta: Badan Penerbit Gama.

Sartono, Agus. (2002) Manajemen Keuangan. Yogyakarta: BPFE.

Sawir, Agnes. (2005) Analisis Kinerja Keuangan Perencanaan Keuangan Perusahaan, Jakarta: PT.Gramedia Pustaka Utama.

Soemarso, (2005) Akuntansi suatu pengantar. Jakarta: Salemba Empat.

Sundjaja, Ridwan, S \& Inge, Barlian. (2009) Manajemen Keuangan Satu, Jakarta : PT. Prehallindo.

Sugiyono. (2008) Metode Penelitian Bisnis, Bandung: Alfabeta

Stice, Skousen, (2005) Intermediate Accounting, Alih Bahasa Safrida Rumandang Parulin, Ahmad Maulana, Jakarta: Salemba empat.

Syamsuddin, L. (2007) Manajemen Keuangan Perusahaan: Konsep Aplikasi dalam: Perencanaan, Pengawasan, dan Pengambilan Keputusan. Edisi Baru, cetakkan kesembilan. Jakarta: PT. Raja Grafindo Persada

Weston, J. Fred \& Thomas E Coopeland. (2010) Manajemen Keuangan, terjemahan JakaWasana dan Kibrandoko, Jakarta : Erlangga.

Wild, John, Subramanyam, K.R (2010) Analisis Laporan Keuangan Buku II, Terjemahan Edisi kesepuluh, Jakarta: Salemba Empat 